\title{
Health Literacy of Students Who Applied to Medical and Nursing Faculty in Dokuz Eylul University
}

\author{
Dokuz Eylül Üniversitesi, Tıp ve Hemşirelik Fakültelerine Başvuran \\ Öğrencilerin, Sağlık Okuryazarlık Düzeyi
}

\author{
Candan Kendir ${ }^{*}$, Kürşad Akkaya ${ }^{1}$, Inan Arslantaş ${ }^{1}$, Mehtap Kartal $^{1}$
}

\begin{abstract}
Introduction: Health literacy (HL) contains to listen and understand complicated readings, ability to analytic and decision making. The purpose of this research to address health literacy of medical and nursing faculty students. Method: The data was collected during registration of the students who applied to medical and nursing faculties in Dokuz Eylul University between 2014-2015. In this research, a sociodemographic questionnaire, REALM (Rapid Estimate of Adult Literacy in Medicine), NVS (Newest Vital Sign) and General Health Survey (GHS) were been used as scales. Results: 585 students joined to research and $88.0 \%$ of them completed the survey. Of the participants, $63.7 \%(\mathrm{n}=328)$ of students were female, $52 \%(\mathrm{n}=268)$ registered form medicine faculty and mean age was $18.3 \pm 0,9$. Of the participants $83.3 \%(\mathrm{n}=423)$ got 2 scores (no risk) and $7.5 \%(\mathrm{n}=38)$ got more than 4 points (has risk) in GHS. According to REALM scale, of the participants $63.6 \%(\mathrm{n}=327)$ have adequate HL level, $36.4 \%(\mathrm{n}=187)$ have limited HL level. According to NVS scale, of the participants $54.8 \%(\mathrm{n}=430)$ have adequate, $30.2 \%$ $(\mathrm{n}=127)$ have limited and 15\% ( $\mathrm{n}=63)$ have inadequate HL level. Conclusion: Medical and nursery faculty students are important for community. In future, since those students will play an important role in health promotion, to define health literacy levels of those students properly and interventions to improve it will lead to positive results both in personal and professional development.
\end{abstract}

Key words: Health literacy, adolescents, medical faculty, nursing faculty

\section{ÖZET}

Amaç: Sağlık okuryazarlığı (SOY), karmaşık okumaları dinleyip anlamayı, analitik ve karar verme becerisini ve bu beceriyi sağlıkla ilgili durumlarda kullanabilmeyi içermektedir. Bu çalışmada amaç, tıp ve hemşirelik fakültelerine başvuran öğrencilerin, să̆lık okuryazarlık düzeylerini ortaya koymaktır. Yöntem: Bu çalışmanın verileri; 2014-2015 eğitim öğretim yılında Dokuz Eylül Üniversitesi (DEÜ) Tıp ve Hemşirelik Fakültelerini kazanan öğrencilerle, sözlü onamları alınarak kayıt sırasında toplanmıştır. Çalışmada, veri toplama aracı olarak 20 soruluk anket ve sağlık okuryazarlığı ölçekleri REALM (Rapid Estimate of Adult Literacy in Medicine) ve NVS (Newest Vital Sign)'nin yanısıra Genel Sağlık Anketi-12 (GSA-12) kullanılmıştır. Bulgular: Çalışmaya, toplam 585 öğrenciden, 515'i katılmış olup cevaplanma oranı \%88'dir. Katılanların $\% 63,7 \quad(n=328)$ 'si kız öğrenciler olup, \%52,0 (n=268)'si tıp fakültesine kayıt olmuş ve yaş ortalamaları 18,3 $\pm 0,9$ 'dur. Katılımcıların \%83,3 ( $\mathrm{n}=423$ )'ü GSA skorundan 2 ve altı (risk yok), \%7,5 (n=38)'i 4 ve üzeri (riskli) puan almıştır. REALM'e göre \%63,6 (n=327)'sı yeterli, \%36,4 (n=187)'ü kısıtlı SOY düzeyine sahiptir. NVS puanına göre ise; katılımcıların $\% 54,8$ $(\mathrm{n}=430)$ 'i yeterli, \%30,2 ( $\mathrm{n}=127)$ 'si kısıtll, \%15,0 $(\mathrm{n}=63)$ '1 yetersiz SOY düzeyine sahiptir. Sonuç: Tıp ve Hemşirelik fakültesini kazanan öğrenciler, yüksek puanlarla bu fakültelere yerleşen, geleceğin sağllk sektörünün temelini oluşturan kişiler oldukları için, toplum açısından önemli bireylerdir. Gelecekte, sağlığın geliştirilmesinde büyük rol oynayacak bu bireylerin, yaş grubuna uygun geliştirilmiş ölçeklerle SOY düzeylerinin belirlenip, yükseltilmesi için müdahaleler yapılması hem bireysel, hem de profesyonel yaşamlarında olumlu sonuçlar doğuracaktır.

Anahtar kelimeler: Sağlık okuryazarlığı, adolesan, tıp fakültesi, hemşirelik fakültesi

\footnotetext{
Received / Geliş tarihi: 13.11.2016, Accepted / Kabul tarihi: 29.05.2017

${ }^{1}$ Dokuz Eylül Üniversitesi Tıp Fakültesi Aile Hekimliği Anabilim Dalı

*Address for Correspondence / Yazışma Adresi: Candan Kendir, Dokuz Eylül Üniversitesi Tıp Fakültesi Aile Hekimliği Anabilim Dalı, İzmir-

TÜRKIYE, E-mail: candankendir@hotmail.com

Kendir C, Akkaya K, Arslantaş İ, Kartal M. Health Literacy of Students who applied to Medical and Nursing Faculty in Dokuz Eylul University. TJFMPC,

2017;11(3): 144-151. DOI: 10.21763/tjfmpc.336167
} 


\section{GíRIŞ}

Sağlık okuryazarlığı (SOY), bireyin sağlığını iyileştirici şekilde temel sağlık bilgilerini ve hizmetlerini edinebilme, yorumlayabilme ve anlayabilme kapasitesi olmakla birlikte, karmaşık okumaları dinleyip anlamayı, analitik ve karar verme becerisini ve bu beceriyi sağlıkla ilgili durumlarda kullanabilmeyi de içermektedir. Kaliteli bir sağlık hizmeti için hastaların, rahatsızlıklarını doğru ifade edebilmeleri ve belirtileri olduğu gibi tanımlayabilmeleri gerekmektedir. Uygun sorular sormalar1, verilen tıbbi önerileri ve tedavi yönergelerini anlayabilmeleri ideal koşullarda beklenen özelliklerdir. ${ }^{1-3}$

Sağlık okuryazarlığı düzeyinin, kronik hastalıkların yönetiminde ve ilaç uyumunda önemli olduğuna dair çalışmalar bulunmaktadır. Özellikle, yaşlı ve düşük sosyoekonomik düzeyi olan bireylerde kronik hastalık görülme riski normal bireylere göre daha yüksektir ve bu bireylerin sağlik okuryazarlığı düzeyleri daha düşüktür. Sağlık okuryazarlığ düşük bireylerin, ilaç uyumunun da düşük olduğu, buna bağlı olarak hastaların acil servis kullanımı, bakımevi gereksinimi ve tanısal test masrafları, gereksiz yere hastane yatışlarının arttığı ve yatış sürelerinin uzadığı gösterilmiştir. ${ }^{4-6}$

Amerika'da, 2013 yılında hazırlanan "Sağlık okuryazarlığını geliştirmek için ulusal eylem planı" (National Action Plan to Improve Health Literacy) programı kapsamında, Amerika'da K-12 devlet okullarında tıbbi derslerde eksiklik olduğu fark edilmiş ve SOY düzeyi yüksek bir birey olabilmek için, adolesan dönemdeki sağllk eğitiminin, erişkin çağdaki hekim-hasta ilişkisi açısından da çok önemli olduğu vurgulanmıştır. ${ }^{7}$

Adolesan çağ, genel alışkanlıkların kazanıldığı ve genel sağlıklı büyüme ve gelişmenin temellerinin atıldığ dönemdir. Adolesan çağ, Dünya Sağlık Örgütü tarafından 10-19 yaş, Türkiye Halk Sağlığı tanımlamalarında ise 12-18 yaş grubunu içermektedir. ${ }^{7-8} \quad$ Yapılan çalışmalara göre; Amerika'da yaşayan çocukların 5 milyonu şu an kronik bir hastalığa sahiptir ve bu çocukların \%90'ının 20 ve üzeri yaşlara kadar yaşaması beklenmektedir. Kronik hastalığı olan çocukların ve adolesanların sağlıklı yaşıtlarına göre, ileride hastalık yönetiminde daha başarılı oldukları ve SOY düzeylerinin daha yüksek olduğu gösterilmiştir. ${ }^{9}$

Meksika'da, 2000 yılında toplanan, 5. Sağlığın Geliştirilmesi konulu Dünya Sağlık Konferansı sonunda, Ratzan ve ark.'larının da belirttiği gibi; sadece kronik hastalığ adolesanların değil, tüm adolesanların sağlık okuryazarlık düzeylerinin yükseltilmesi, erişkin dönemde sağlık bilgisini daha iyi anlama, doğru sağlık davranışı oluşturmaları ile doğrudan ilişkilidir. ${ }^{10}$

Tıp fakültesi ve hemşirelik fakültesi öğrencilerinin, sağlık okuryazarlık düzeyi de bu gençlerin gelecekteki sağlık davranışlarında ve geleceğin sağlık çalışanları olarak toplumun sağlık okuryazarlık düzeyinin geliştirilmesinde önemlidir. $\mathrm{Bu}$ alanda yapılan bir çalışma, aynı zamanda adolesanların riskli sağlık davranışları için bir belirteçtir.

Bu çalışmada, Dokuz Eylül Üniversitesi Tıp Fakültesi ve Hemşirelik Fakültesi'ne girmeye hak kazanmış öğrencilerin, sağlık okuryazarlık düzeylerinin belirlenmesi amaçlanmıştır.

\section{YÖNTEM}

Sağlık okuryazarlığı düzeyini ortaya koymayı amaçlayan bu çalışma, 2014-2015 eğitim öğretim yılında, DEÜ Tıp ve Hemşirelik Fakültelerine yeni kayıt olan öğrencilerle yapılmıştır. Araştırmanın verileri Eylül 2014'te kayıt sırasında sözlü onamları alınarak toplanmış olup, anket uygulaması öncesinde tüm öğrenciler çalışma ile ilgili olarak bilgilendirilmiştir. Araştırma verileri fakülteye kayıtları sırasında daha önceden eğitim verilmiş anketörler tarafindan birebir görüşmelerle toplanmıştır. Çalışma 585 öğrencinin $515^{\prime} \mathrm{i}$ ile tamamlanmış olup cevaplanma oranı \%88'dir. DEÜ Tıp fakültesi ögrrencilerinin toplam sayısı 298 olup, cevaplama oranı \%90'dır. Hemşirelik öğrencilerinin toplam sayısı 287 olup, cevaplama oranı \%86'dır.

Çalışmada veri toplama aracı olarak, 20 soruluk anket ve sağlık okuryazarlığı ölçekleri REALM ve NVS'nin yanısıra Genel Sağlık Anketi12 (GSA-12) kullanılmıştır. Ankette öğrencilerin sosyodemografik özellikleri, hastalık durumları, ilaç ve sağlı hizmeti kullanımları, sigara ve alkol kullanımları günlük tüketim miktar üzerinden sorgulanmış, bunun yanında egzersiz yapma durumlar1, Dünya Sağlık Örgütü'nün (DSÖ) uluslararası BKI'leri hesaplanması amaciyla boy ve ağırlıkları yer almıştır. Buna göre BKI $<18,5 \mathrm{~kg} / \mathrm{m}^{2}$ ve altı düşük kilolu, $18.5-24.9 \mathrm{~kg} / \mathrm{m}^{2}$ arasında ise normal kilolu, 25-29.9 $\mathrm{kg} / \mathrm{m}^{2}$ arasında ise fazla kilolu ve $30 \mathrm{~kg} / \mathrm{m}^{2}$ ve üzeri obez olarak değerlendirilmiştir.

SOY ölçekleri olan REALM ve NVS'nin Türkiye'de; 456 hasta üzerinde yapılan bir çalışmada Türkçe geçerlilik-güvenirlik çalışması yapılmıştır. ${ }^{11}$

REALM ölçeğinde, 66 tıbbi terim (osteporoz, testis, vb) kolaydan zora gidecek şekilde sıralanmıştır. $\mathrm{Bu}$ ölçekte, hastaya tanıdık gelen terimlerin sayısına göre okuryazarlık puanlaması yapılmaktadır. Hastaya bildiği kelimeleri yüksek 


\section{Original Research / Özgün Araştırma}

sesle söylemesi söylenerek, hastanın bilmediği kelimeleri atlaması beklenir. Hasta, kelimeleri söylerken anketi yapan kişi de eşzamanlı olarak puanlamayı yapmaktadır. REALM ile okuryazarlık şu şekilde değerlendirilmektedir:

- 0 - 18 arası puan alanların değerlendirilmesi (yetersiz SOY düzeyi): 3. sinıf ve altı düzeyinde (Basit seviyedeki eğitim malzemesini bile okuyamaz, tekrar tekrar anlatmak gerekir. Görsel ve işitsel malzemeler kullanılmalıdır.)

- 19 - 44 arası puan alanların değerlendirilmesi (yetersiz SOY düzeyi): 4-6. sinıf düzeyinde (Basit seviyedeki eğitim malzemeleri kullanılmalıdır, ilaç kullanma talimatlarını okuyamayabilir.)

- $45-60$ arasi puan alanların değerlendirilmesi (kısıtlı SOY düzeyi): 7-8. sınıf düzeyinde (Çoğu eğitim malzemesi ile baş edebilir. Basit eğitim malzemesi vererek küstürülmemelidir.)

- 61 - 66 arasi puan alanların değerlendirilmesi (yeterli SOY düzeyi): Lise düzeyinde (Çoğu eğitim malzemesini okuyabilir.) olarak yapılmaktadır.

NVS ölçeğinde ise; hastaya bir dondurmanın içerdiği besin değerlerini gösteren bir tablo gösterilerek, incelemesi istenir. Ardından bu tablodaki değerlere göre, besin değerleri ile ilgili çeşitli (alınan kalori, alerji riski, vb.) hesaplamaları içeren 6 soruyu yanıtlaması istenir. ${ }^{11}$ Yapılacak olan NVS anketi sonunda;

- 0 - 1 puan alanlar; sınırlı sağlık okuryazarlık düzeyi

- 2 - 3 puan alanlar; sınırlı sağlık okuryazarlık düzeyi riski

- 4 - 6 puan alanlar; yeterli sağlık okuryazarlık düzeyi olarak değerlendirilir.

GSA-12, genel ruhsal sağlik durumunu belirlemek üzere Goldberg (1972) tarafindan geliştirilmiş, toplumda ve birinci basamak sağlık kuruluşlarında ruhsal durumu saptamak amaciyla uygulanan, kişinin kendisinin doldurduğu bir testtir. Türkiye'de, geçerlilik ve güvenilirlik çalışmaları 1996 yılında Kılıç tarafindan gerçekleştirilmiş ve Cronbach's alfa değeri 0,78 olarak hesaplanmıştır. Testin değerlendirilmesinde; yanıtların a ve b şıklarına "0", c ve d şıkları için " 1 ” puan verilir, böylece katılımcıların puanları 0-12 arasında değişmektedir. Alınan puanlara göre ruhsal hastalık yönünden 2 'den az puan düşük, 2-3 puan orta, 4 ve daha yüksek puan yüksek risk olarak değerlendirilmiştir.

İstatistiksel değerlendirmede, "SPSS 15.0 for Windows" paket programı kullanılmıştır. Veriler aritmetik ortalama \pm standart sapma değerleri ile sayı ve yüzde değerleri gösterilmiştir. İki grup ortalamasının karşılaştırılmasında Student $t$ testi kullanılmış; ikiden fazla gruba ait ortalamanın karşılaştırılmasında, One Way ANOVA testi ve sonrasinda post hoc için ise Tukey testi kullanılmıştır. İstatistiksel anlamlılık için p değeri $<0,05$ olarak kabul edilmiştir.

\section{BULGULAR}

Öğrencilerin \%52,0 (n=268)'si tıp, \%48,0 (n=247)'i hemşirelik fakültesine kayıt olan öğrencilerdir. Öğrencilerin \%63,7 (n=328)'sini k1z öğrenciler oluştururken, öğrencilerin yaş ortalamaları 18,3 $\pm 0,9$ 'dur (Tablo 1).

Çalışmaya katılan öğrencilerin alışkanlıklarına ait özellikleri Tablo 1'de yer almaktadır. Öğrencilerin \%95,3’ü $(n=490)$ hiç sigara içmemiștir. Sigara içen veya içmeyi bırakanların, sigara kullanım miktarı 1-30 paket/yıl arasında değişmektedir. Öğrencilerin \%24,2 (n=124)'si düzenli egzersiz yapmakta olup, ortalama günde $51,8 \pm 30,4$ dakika ve haftada $3,4 \pm 1,7$ gün egzersiz yapmaktadırlar. Öğrencilerin \%13,0 (n=66)'ünün BKI'i 25 ve üzerindedir.

Öğrencilerin, ölçek puanları ve bilgilendirmeye yönelik verilen materyallere ilişkin değerlendirmeleri Tablo 2'de yer almaktadır. Öğrencilerin ortalama GSA puanı $0,8 \pm 1,6$ (minmaks: 0-12), REALM puanı 61,2 $\pm 3,2$ (min-maks: 066) ve NVS puanlar1 ise $3,4 \pm 1,6$ (min-maks: $0-6$ ) olarak hesaplanmıştır. Katılımcıların \%83 ( $\mathrm{n}=423$ )'ünün GSA skoru 2 puanın altında (düşük risk), \%9,3 (n=47)'ü 2-3 puan, $\% 7,5(n=38)$ 'i 4 puan ve üzeri (orta risk) almıştır. REALM ölçeğine göre bireylerin \%63,6's1 “yeterli", \%36,4'ü "kısıtlı" sağlık okuryazarlık düzeyindedir. NVS ölçeğinde ise; bireylerin \%54,8'i "yeterli", \%30,2'si "k1sitll", $\% 15,0$ '1 da "yetersiz" sağlık okuryazarlık düzeyinde bulunmuştur. Bireylere sağlık kuruluşlarında kendilerine verilen kağıtları ve broşürleri okuma ve anlama durumları sorulmuştur. Buna göre, bireylerin \%6,6'sı sağlık kuruluşlarında kendilerine verilen kağıtları okuma durumunu cevapsız bırakmıştır. Kağıtlarda yazanları anlama durumları sorulduğunda, bireylerin \%29,2 (n=150)'si ara sira anladığını, \%70 (n=360)'i çoğunlukla anladığını ifade ederken, bireylerin \%4,5 (n=23)'i verilen broşürleri okumadan çöpe attığını belirtmiş.

Tablo 2'de öğrencilerin bazı özelliklerine göre, GSA, REALM ve NVS puanlarının karşılaştırılmalarına ilişkin bulguları gösterilmektedir. Öğrencilerin, GSA puanları sadece düzenli egzersiz yapma durumları açısından istatistiksel olarak anlamlı farklıdır $(p=0,008)$. Düzenli egzersiz yapanların GSA puanları (ortalama puan $0,9 \pm 1,7$ ), yapmayanlara (ortalama puan $0,5 \pm 1,3)$ göre düşüktür. REALM puan ortalamaları 


\begin{tabular}{|c|c|c|}
\hline Tablo 1. Öğrencilerin bazı sosyodemografik özellikleri ve sağlık davranışları (n=515) & $\mathrm{n}$ & $\%$ \\
\hline \multicolumn{3}{|l|}{ Calıșma durumu } \\
\hline Çalıșmıyor & 511 & 99,2 \\
\hline Çalıșıyor & 4 & 0,8 \\
\hline \multicolumn{3}{|l|}{ Hastalık durumu $(\mathrm{n}=514)$} \\
\hline Yok & 494 & 96,1 \\
\hline Var & 20 & 3,9 \\
\hline \multicolumn{3}{|l|}{ İlaç kullanımı } \\
\hline Yok & 499 & 96,9 \\
\hline Var & 16 & 3,1 \\
\hline \multicolumn{3}{|l|}{ Hastaneye yatıș $(\mathrm{n}=513)$} \\
\hline Hiç yatmamıș & 355 & 69,2 \\
\hline Bir kez & 110 & 21,4 \\
\hline İki kez & 31 & 6,0 \\
\hline Üç kez ve üzeri & 17 & 3,3 \\
\hline \multicolumn{3}{|l|}{ Bir ayda sağlık kurumuna bașvuru sayısı $(n=467)$} \\
\hline Bir kez & 410 & 87,8 \\
\hline İki kez & 42 & 9,0 \\
\hline Üç kez ve üzeri & 15 & 3,2 \\
\hline \multicolumn{3}{|l|}{ Sigara kullanımı $(n=514)$} \\
\hline Hiç kullanmamıș & 490 & 95,3 \\
\hline Bırakmıș & 5 & 1,0 \\
\hline Halen kullaniyor & 19 & 3,7 \\
\hline \multicolumn{3}{|l|}{ Alkol kullanımı $(\mathrm{n}=510)$} \\
\hline Kullanmiyor & 473 & 92,7 \\
\hline Kullaniyor & 37 & 7,3 \\
\hline \multicolumn{3}{|l|}{ Düzenli egzersiz $(\mathrm{n}=512)$} \\
\hline Yapmiyor & 388 & 75,8 \\
\hline Yapıyor & 124 & 24,2 \\
\hline \multicolumn{3}{|l|}{ Beden kitle indeksi $(\mathrm{n}=509)$} \\
\hline <18,5 (Düșük kilolu) & 73 & 14,3 \\
\hline 18,5-24,9 (Normal kilolu) & 370 & 72,7 \\
\hline 25,0-29,9 (Fazla kilolu) & 59 & 11,6 \\
\hline$\geq 30,0$ (Obez) & 7 & 1,4 \\
\hline
\end{tabular}

\begin{tabular}{|l|l|l|}
\hline Tablo 2. Öğrencilerin ölçek puanları ve SOY sorularına yanıtları (n=515) & \multicolumn{2}{l|}{$\%$} \\
\hline GSA (n=508) & 423 & 83,3 \\
\hline$<2$ & 47 & 9,3 \\
\hline $2-3$ & 38 & 7,5 \\
\hline$\geq 4$ & & \\
\hline REALM (n=514) & 187 & 36,4 \\
\hline $45-60$ & 327 & 63,6 \\
\hline $61-66$ & & \\
\hline NVS (n=420) & 63 & 15,0 \\
\hline $0-1$ & 127 & 30,2 \\
\hline $2-3$ & 430 & 54,8 \\
\hline $4-6$ & & \\
\hline Sağlık kuruluşlarında bana verilen kağıtları (n=515) & 467 & 90,7 \\
\hline Her zaman kendim okurum & 13 & 2,5 \\
\hline Refakatçime okuturum & 1 & 0,2 \\
\hline Sağlık personeline okuturum & 34 & 6,6 \\
\hline Cevapsiz & & \\
\hline Sağlık kuruluşlarında bana verilen kağıtlarda yazılanları (n=514) & 360 & 70,0 \\
\hline Coğunlukla anlarım & 150 & 29,2 \\
\hline Ara sıra anlarım & 4 & 0,8 \\
\hline Hiç anlamam & & \\
\hline Sağlık kuruluşlarında bana verilen kağıtları veya broşürleri (n=514) & 488 & 94,9 \\
\hline Okurum & 3 & 0,6 \\
\hline Başkasına okuturum & 23 & 4,5 \\
\hline Okumadan çöpe atarım & & \\
\hline
\end{tabular}




\begin{tabular}{|c|c|c|c|}
\hline & GSA Puanı & REALM Puan 1 & NVS Puan1 \\
\hline \multicolumn{4}{|l|}{ Cinsiyeti $(\mathrm{n}=515)$} \\
\hline Erkek & $0,8 \pm 1,7$ & $60,4 \pm 3,5$ & $3,5 \pm 1,6$ \\
\hline K1z & $0,8 \pm 1,6$ & $61,6 \pm 3,0$ & $3,4 \pm 1,5$ \\
\hline$p$ değeri & 0,949 & $<0,001$ & 0,294 \\
\hline \multicolumn{4}{|l|}{ Fakülte $(n=515)$} \\
\hline Tip & $0,8 \pm 1,7$ & $60,3 \pm 3,6$ & $3,8 \pm 1,4$ \\
\hline Hemșirelik & $0,8 \pm 1,5$ & $62,1 \pm 2,5$ & $2,8 \pm 1,6$ \\
\hline$p$ değeri & 0,865 & $<0,001$ & $<0,001$ \\
\hline \multicolumn{4}{|l|}{ Hastalık durumu $(\mathrm{n}=514)$} \\
\hline Yok & $0,8 \pm 1,7$ & $61,1 \pm 3,2$ & $3,4 \pm 1,6$ \\
\hline Var & $0,8 \pm 1,6$ & $62,4 \pm 3,0$ & $3,8 \pm 1,8$ \\
\hline$p$ değeri & 0,854 & 0,407 & 0,082 \\
\hline \multicolumn{4}{|l|}{ Hastaneye yatıs $(\mathrm{n}=513)$} \\
\hline Hiç yatmamıs & $0,7 \pm 1,5$ & $61,2 \pm 3,0$ & $3,4 \pm 1,6$ \\
\hline En az bir kez yatmıș & $1,0 \pm 1,9$ & $61,2 \pm 3,7$ & $3,6 \pm 1,6$ \\
\hline$p$ değeri & 0,060 & 0,975 & 0,258 \\
\hline \multicolumn{4}{|l|}{ Sigara kullanımı $(n=514)$} \\
\hline Hiç içmemiș & $0,8 \pm 1,5$ & $61,2 \pm 3,2$ & $3,4 \pm 1,6$ \\
\hline İcen ve içip bırakan & $1,6 \pm 3,0$ & $61,4 \pm 2,6$ & $3,5 \pm 1,7$ \\
\hline p değeri & 0,189 & 0,407 & 0,887 \\
\hline \multicolumn{4}{|l|}{ Alkol kullanımı $(\mathrm{n}=510)$} \\
\hline Hayır & $0,8 \pm 1,6$ & $61,2 \pm 3,2$ & $3,4 \pm 1,6$ \\
\hline Evet & $1,6 \pm 2,8$ & $61,5 \pm 2,9$ & $4,1 \pm 1,5$ \\
\hline$p$ değeri & 0,379 & 0,514 & 0,011 \\
\hline \multicolumn{4}{|l|}{ Düzenli egzersiz $(\mathrm{n}=512)$} \\
\hline Hayır & $0,9 \pm 1,7$ & $61,1 \pm 3,3$ & $3,4 \pm 1,6$ \\
\hline Evet & $0,5 \pm 1,3$ & $61,3 \pm 3,1$ & $3,6 \pm 1,6$ \\
\hline$p$ değeri & 0,008 & 0,514 & 0,112 \\
\hline \multicolumn{4}{|l|}{ Beden kitle indeksi $(\mathrm{n}=509)$} \\
\hline$<18,5$ & $0,8 \pm 1,4$ & $61,6 \pm 2,5$ & $3,0 \pm 1,8$ \\
\hline $18,5-24,9$ & $0,8 \pm 1,7$ & $61,1 \pm 3,3$ & $3,5 \pm 1,5$ \\
\hline$\geq 25,0$ & $0,9 \pm 1,4$ & $61,0 \pm 3,5$ & $3,6 \pm 1,5$ \\
\hline p değeri & 0,963 & 0,511 & 0,087 \\
\hline
\end{tabular}

.ise öğrencilerin cinsiyetlerine ve kayıt oldukları okullara göre farklı bulunmuştur. Kızların (ortalama puan $61,6 \pm 3,0$ ) erkeklere (ortalama puan $60,4 \pm 3,5$ ) ve hemşirelik öğrencilerinin (ortalama puan $62,1 \pm 2,5$ ) tıp öğrencilerine (ortalama puan $60,3 \pm 3,6$ ) göre REALM puanları istatistiksel olarak anlamlı yüksektir $(p<0,001)$. NVS puan ortalamaları ise okul ve alkol kullanımı açısından farklı bulunmuştur. Tıp öğrencilerinin (ortalama puan $3,8 \pm 1,4$ ) hemşirelik öğrencilerine (ortalama puan 2,8 $\pm 1,6$ ) göre $(\mathrm{p}<0,001)$ ve alkol alanların (ortalama puan $4,1 \pm 1,5)$

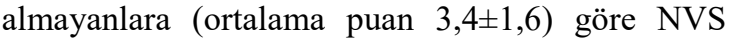
puanları istatistiksel olarak anlamlı yüksektir $(\mathrm{p}=0,011)$.

\section{TARTIŞMA}

Son yıllarda, dünya ile aynı anda ülkemizde de SOY kavramına artan ilgi, literatürde yer alan makalelerin artışına neden olmuştur. Diğer yandan, yapılmış bu çalışmalarda yer alan örneklem erişkin yaş grubundan oluşmakta olup, adolesan dönem SOY düzeyine ilişkin kısıtlı sayıda çalışma bulunmaktadır.
Adolesan dönem için yapılan çalışmaların az olması ve bu yaş grubu için hangi ölçeğin kullanılmasının daha uygun olduğu konusunda tartışmalar yer almaktadır. Davis ve arkadaşlarının 2006 yılında yaptığı çalışmada, REALM testinin İngilizce uygulamada adolesan dönemde en yüksek geçerlilik ve güvenirliğe sahip olduğu gösterilmiştir. ${ }^{12}$ Bunun yanında, REALM ölçeği sınırlı SOY düzeyi ile sınırlı SOY riski arasında ayrım yapabilirken, düşük SOY düzeyinin tespitinde yetersiz kalmaktadır. Tam da bu noktada, ikinci bir SOY ölçeği kullanma gereksinimi doğmaktadır. NVS hem hızlı uygulanabilir olması, hem de analitik SOY düzeyini ölçmesi ile birçok çalışmada REALM ile birbirini tamamlayıcı şekilde kullanılmıştır.

Bu çalışmada, REALM ölçeğinde elde edilen sonuçlar ile NVS ölçeğinde elde edilen sonuçlar arasında farklılıklar bulunmuştur. Bireylerin, \%63,6's1 REALM ölçeğine göre yeterli SOY düzeyine sahip, \%36,4'ü kısitlı SOY seviyesinde bulunmuştur. NVS ölçeğine göre ise; bireylerin $\% 54,8$ 'i yeterli SOY düzeyine sahip iken, \%30,2'si kısıtl1, \%15,0'i yetersiz SOY düzeyine sahip 
bulunmuştur. Zhang ve ark.'larının, SOY anketini (HLQ- Health literacy questionnaire) kullanarak Dönem I, Dönem II ve Dönem III tıp fakültesi öğrencisinden oluşan 1272 katılımcıyla yaptığı bir çalışmada, öğrencilerin \%20,4'ü düşük SOY düzeyine sahipken, yalnızca \%5,7'si yüksek SOY düzeyine sahiptir. ${ }^{13} \mathrm{Bu}$ durum, sağlık bilgisi edinebilme, yorumlama, anlama, analitik karar verme, vb. SOY alt grupları ve kullanılan ölçeklerin farklı alt grupları ölçmesi ile açıklanabilir. Bireylerin okuma-anlama düzeyleri daha yüksek olmakla birlikte matematiksel düzeyleri veya sağlık personeli iletişimi daha düşük olabilmektedir. Türkiye'de bilinen en geniş örneklemli SOY düzeyini belirlemeye yönelik çalışma, Sağlık ve Sosyal Hizmet Çalışanları Sendikası önderliğinde Aralık 2014 yılında başlatılan "Türkiye Sağlık Okuryazarlık Düzeyi” çalışması Avrupa Birliği tarafindan finanse edilmiş ve HLS-EU (Sağlık Okuryazarlığı Ölçeği- Avrupa Birliği) ölçeği kullanılarak yapılmıştır. Bu araştırma, kesitsel tipte yürütülmüş ve 12 bölgeden rastgele 23 il seçilmiş ve 4924 kişinin katılımı sağlanmıştır. Bu araştırmaya göre, katılımcıların yaş ortalaması $41,4 \pm 0,3$ olup, Türkiye genel sağlık okuryazarlık indeksi 30,4 olarak bulunmuş ve değerlendirme sonuçlarına göre, toplumun \%24,5'inin "yetersiz", \%40,1'inin "sorunlu" SOY düzeyine sahip olduğu belirlenmiştir. ${ }^{14}$

Bunun dişında farklı gruplarda yapılan çalışmalar incelendiğinde, Çorum ilinde 500 ilköğretim okulu öğretmeninin katılımıyla yapılan bir çalışmada, katılımcıların SOY düzeyi NVS (Newest Vital Sign; En yeni yaşamsal belirteç) ile değerlendirilmiş ve \%44'ü çok kısıtlı \%29,8'i kısıtlı SOY düzeyine sahip bulunmuştur. ${ }^{15}$ Yine üçüncü basamak bir hastanede, 40-69 yaş arası kadınlar ile yapılan bir çalışmada, katılımcıların SOY düzeyi REALM (Rapid Estimate of Adult Literacy in Medicine-Tıpta erişkin okuryazarlığının hızlı değerlendirilmesi) ölçeği ile değerlendirilerek, \%44,7'si yetersiz, \%49,3'ü kısıtlı SOY düzeyinde bulunmuştur. ${ }^{16}$

Özdemir ve ark.'larının da, yine üçüncü basamak bir sağlık kuruluşunda, 456 erişkin hasta (yaş ortalaması 36,2 $\pm 12,6$ ) üzerinde yaptıkları çalışmada benzer sonuçlara ulaşmışlardır. Ancak, bu çalışmada yer alan gençlerin NVS puanları, Özdemir ve arkadaşlarının çalışmasında ulaşılanların yaklaşık 2 katı kadardır. ${ }^{11} \mathrm{Bu}$ durum, katılımcıların farklı yaş gruplarında olmaları kadar bizim çalışmadaki gençlerin hepsinin hem lise mezunu, hem de üniversite sınavında tıp ve hemşirelik fakültelerini kazanacak kadar başarılı olmaları önemli bir etkendir. Bu gençlerin girdikleri sınavlar nedeniyle, matematiksel işlemlere daha yatkın ve seçtikleri alan itibariyle de sağlık alanına ve bu alanda kullanılan terimlere yakın ve ilgili olmalarına bağlanabilir.
Çalışmaya dahil olan gençler, sağlıklı yaşam davranışlarına da oldukça yatkın görülmektedir. Çalışmaya katılan öğrencilerin, yalnızca \%3,7'si sigara içerken, 2002 ve 2008 y1lları arasında farklı üniversitelerin tıp fakültelerinde yapilan çalışmalarda bu oran \%43 ile \%64,4 arasında değişkenlik göstermektedir. ${ }^{17,18} 2009$ y1lında üniversitemiz Tıp fakültesi Dönem I öğrencilerinde yapılan bir çalışmada, sigara içme oranı \%29,1 olarak değerlendirilmiş ve tıp fakültesine giren gençlerde sigara içme oranının yıllar geçtikçe azalma gösterdiği tespit edilmiştir. ${ }^{19}$ Alkol kullanımı açısından değerlendirildiğinde, bu çalışmada gençlerin \%7,3'ü alkol kullanıyorken, benzer çalışmalarda bu oran \%70,8 ile \%72,3 arasında değişmektedir. Sigara gibi, alkol kullanımında da yıllar içerisinde azalma gözlenmektedir. Gençlerin sadece \%1,4'ünün obez ve \%11,6'sının ise fazla kilolu olması da gençlerin gösterdikleri sağlıklı yaşam davranışlarına ait değerlendirmeyi destekleyen bir etmendir. 2010 y1lında, yine Dönem 1'e kayıtlı 184 öğrenciye yapılan anket uygulamasında öğrencilerin düzenli egzersiz yapma oranı \%24,6 olarak bulunurken, bu çalışmada bu oran \% 75,8 ile çok daha yüksek tespit edilmiştir. ${ }^{17-20}$ $\mathrm{Bu}$ bulgulara göre, sigara içme ve alkol kullanma davranışlarında yıllar içinde görülen değişim, jenerasyonun değişimi ile SOY düzeyinde de yıllar içinde farklılık gösterebilir. Önümüzdeki yıllarda benzer çalışmaların yapılması, bu değişimi ortaya koymak açısından önemlidir.

Çalışmamızda, kız öğrencilerin SOY düzeyi, erkek öğrencilere göre daha yüksektir. Bu durum Taiwan'da Lee ve ark.'larının yaptığı çalışmanın sonuçlarıyla farklı bulunmuştur. Aradaki bu fark, Lee ve ark.'larının SOY düzeyini ölçerken "bireylerin kendi beyanı" yöntemini kullanması ve erkeklerin kendi sağlık durumlarını abartılı anlatmaları ile açıklanabilir. ${ }^{21}$ Kobayashi ve ark.' larının İngiltere'de yapmış oldukları çalışmada ise, bizim çalışmamıza benzer sonuçlar elde edilmiştir. ${ }^{4}$

Çalışmamızda, bireylerin kendi beyanlarıyla yanıtladıkları sağlık hizmetlerini anlama ve kullanma durumlarıyla ilgili (SOY ile ilişkili) olduğu düşünülen 3 soru yer almaktayd. Hem ölçek ile SOY ölçümü, hem de kendi beyanı ile SOY düzeyini değerlendirme, bizim çalışmamızı karşılaştırma yapabilmesi nedeniyle önemli kılmaktadır. Buna göre, hem REALM, hem NVS'ye göre bireylerin \%50'sinden fazlasının SOY düzeyi yeterli düzeyde bulunmasına rağmen, sağlık kuruluşlarında kendilerine verilen kağıtları \%6,6's1 cevapsız bırakmakta ve $\% 2,5$ 'i refakatçisine okutturmaktadır. Özdemir ve ark.'larının, erişkinlerde aynı sorulara aldıkları yanıtlara göre ise, bireylerin $\% 7,8$ 'i refakatçisine okuturken, \%5,2'si 


\section{Original Research / Özgün Araştırma}

sağlık personeline okutmayı tercih etmekteydi. Bireylerin yazılı materyalleri anlamalarına yönelik sorulara, bizim çalışmamıza katılanların \%29,2'si ara sıra anlarım yanıtı verirken, Özdemir ve ark.'larının çalışmasında bu oran \%50'iydi. Bu durum, gençlerin okudukları şeylere daha iyi odaklanabilmeleri ve eğitime daha uygun olabilmeleri ile açıklanabilir. Çalışmamıza katılan bireylerin \%4,5'i yazılı materyalleri hiç okumadan çöpe attığını belirtirken, Özdemir ve ark.'larının çalışmasında bu oran $\% 7,8$ olarak karşımıza çıkmaktaydı. ${ }^{14}$

Çalışmamıza göre, hemşirelik fakültesine başlayacak olan öğrencilerin REALM puanları, tıp fakültesine girmeye hak kazanmış bireylere göre daha yüksektir. Hemşirelik fakültesi öğrencileri, REALM puan ortalamalarına göre yeterli SOY düzeyinde iken, tıp fakültesi öğrencileri, kısıtlı SOY düzeyinde bulunmuştur. Hemşirelik fakültesi öğrencilerinin, en azından bir kısmı sağlık meslek lisesi mezunu olabilir. Yapılan ankette bu bilgi sorulmadığından, hemşirelik öğrencilerinin bir kısmının bu nedenle liseden itibaren medikal terimlere yatkın olmasına bağlı bu farklılık ortaya çıkmış olabilir. NVS puanları açısından değerlendirildiğinde ise, tam tersi bir durum söz konusu olup, tıp fakültesi öğrencilerinin puanları, hemşirelik fakültesi öğrencilerine göre daha yüksek bulunmuştur. Tip fakültesi öğrencilerinin puan ortalamaları 3,8 $\pm 1,4$ olup, kısıtlı SOY düzeyinde değerlendirilirken, hemşirelik fakültesi ögrencilerinin puan ortalamaları 2,8 $\pm 1,6$ olup, yetersiz SOY düzeyinde olarak değerlendirilmektedir. Literatürde benzer örneklere rastlanmamıştır, ancak NVS puanlamaları arasındaki bu fark, NVS ölçeğinin matematiksel hesaplamalara dayanmasına ve liseyi bitirdikten öğrencilerin üniversiteye girebilmek için girdikleri sınavda, tıp fakültesi öğrencilerinin, hemşirelik fakültesi öğrencilerine göre sayısal alanda daha yüksek puan alarak kazanmalarına bağlı olabilir. Çalışmaya katılan 106 öğrenci, REALM ölçeğini yanıtlayıp, NVS ölçeğini yanıtsız bırakmıştır. Bu durumun, kayıt işlemleri sırasında kısıtlı zamana ve REALM anketi yüz yüze yapıldığından tam yanıt alınmasına karşıt, NVS anketleri dağıtılarak bireylerin kendilerinin doldurmasının istenmesine bağlı olduğu düşünülmektedir.

Adolesan veya çocukluk döneminde, kronik hastalığı olanların SOY düzeyi daha yüksekmiş gibi görünse de belirgin bir yükseklik saptanmamıştır. Elizabeth L. Perley ve ark.'larının 2014 yılında yazdığı derlemede, adolesan dönemde sağlık okuryazarlık düzeyi ölçümünde, uygun ölçek kullanımında ve uygun müdahale uygulanmasında ciddi sıkıntılar bulunduğu ifade edilmektedir ${ }^{12}$.

\section{SONUÇ}

Çalıșmamızın sonuçlarına göre, tıp ve hemșirelik fakültesine başvuran öğrencilerin, üçte biri REALM'e göre, yaklaşık yarısı NVS'ye göre kısıtlı veya yetersiz SOY düzeyine sahiptir. Tip ve Hemşirelik fakültesini kazanan öğrenciler, yüksek puanlarla bu fakültelere yerleşen, geleceğin sağlik sektörünün temelini oluşturacak kişilerdir. Bunun yanı sıra, bu bireyler toplum açısından önem arz eden adolesan yaş grubuna ait bireylerdir. Aile hekimliği, toplumda her yaş kesiminde olduğu gibi adolesan sağlığında da önemli bir yere sahiptir. Tekrarlayan hasta görüşmeleri, sağlığı geliştirme firsatlarının değerlendirilmesi ile, adolesan bireylerin SOY düzeyi birinci basamakta yükseltilme imkanına sahiptir. Aile hekimliği uygulamas1 ile bu bireyler adolesan ve takibinde, erişkin çağda yeterli SOY düzeyine sahip bireyler olabilir. İleri dönemlerde, adolesan yaşta farklı müdahale çalışmaları ile bu bireyleri SOY düzeylerinin yükseltilmesi hem bireysel, hem de profesyonel gelişimleri ile toplum sağlığ geliştirilmesi açısından önem arz etmektedir. Bu durum da, yüksek SOY düzeyine sahip bir toplum zemininde sağlık hizmetlerinin maliyetinin etkin kullanılmasına ve ortalama yaşam süresinin artışına imkan verecektir.

Yazarların makaleleriyle ilgili çıkar çatışması bulunmamaktadir.

Araştırma, "20th WONCA EUROPE CONFERENCE" (Halic Congress Center Istanbul, October 22-25, 2015)'de sözel bildiri olarak sunulmuştur.

\section{KAYNAKLAR}

1. World Health Organization. 7th Global conference on health promotion. Track themes: Track. 2009;1. Erişim tarihi: 15.03.2017, http://www.who.int/healthpromotion/conferenc es/7gchp/track2/en/

2. Kindig DA, Panzer AM, Nielsen-Bohlman L, editors. Health literacy: a prescription to end confusion. National Academies Press; 2004 Jul 29:25-27. Erişim tarihi: 10.02.2017, http://www.nap.edu/openbook.php?record_id= 10883

3. Sorensen K, van den Broucke, Fullam J, Doyle G, Pelikan J, Slonska Z et al. Health literacy and public health: A systematic review and integration of definitions and models. BMC Public Health 2012, 12-80

4. Kobayashi LC, Wardle J, von Wagner C. Limited health literacy is a barrier to colorectal cancer screening in England: evidence fromthe 
English Longitudinal Study of Ageing. PrevMed.2014;61:100-5.

5. Dageforde LA, Cavanaugh KL. Healthliteracy: emerging evidence and applications in kidney disease care. Adv Chronic Kidney Dis. 2013;20(4):311-9.

6. Sadeghi S, Brooks D, Stagg-Peterson S, Goldstein R. Growing awareness of the importance of health literacy in individuals with COPD. COPD. 2013;10(1):72-8.

7. U.S. Department of Health and Human Services, Office of Disease Prevention and Health Promotion. (2010). National Action Plan to Improve Health Literacy. Washington, DC: Author. Adolescent health, World Health Organization (WHO), 33-34, Erişim tarihi: 06.03.2017,http://www.who.int/topics/adolesce nt health/en/

8. Adolesan ve Genç Sağlığı Gelişim Programı, Türkiye Halk Sağlığı Kurumu Çocuk ve Ergen Sağlığı Daire Başkanlığı, Erişim tarihi: 25.05.2017, http://cocukergen.thsk.saglik.gov.tr/dairefaaliyetleri/adolesan-ve-genc-sagligi/748adolesan-ve-genç-sağlığı-ve-gelişimiprogrami.html

9. Perly EL. Health literacy in adolescents: an integrative review. J Spec Pediatr Nurs. 2014;19(3):210-8.

10. Ratzan SC, Health literacy: communication for the public good, Health Promot. Int. (2001) 16 (2):207-214.

11. Ozdemir H, Alper Z, Uncu Y, Bilgel N. Health literacy among adults: a study from Turkey. Health Educ Res (2010) 25 (3): 464-477.

12. Murphy PW, Davis TC, Long SW, Jackson RH, Decker BC. Rapid Estimate of Adult Literacy in Medicine (REALM): A Quick Reading Test for Patients, Journal of Reading 37.2 (1993)10: 124-130
13. Zhang Y, Zhang F, Hu P, Huang W, Lu L, Bai $\mathrm{R}$ et al. Exploring Health Literacy in Medical University Students of Chongqing, China: A Cross-Sectional Study. PloS one 11.4 (2016): 47.

14. Durusu Tanriöver M, Yıldırım HH, Demiray Ready FN, Çakır B, Akalın HE. Türkiye sağlık okuryazarlığı araştırması. 1. Baskı, Sağlık-Sen Yayınları, Ankara, 2014, s. 42-47, Erişim tarihi: 06.02.2017,

http://www.sagliksen.org.tr/cdn/uploads/galler y/pdf/8dcec50aa18c21cdaf86a2b33001a409.pd $\mathrm{f}$

15. Yilmazel G, Çetinkaya F. Health literacy among schoolteachers in Çorum, Turkey. Eastern Mediterranean Health Journal 2015; 21(8):598605

16. Yilmazel G. Health Literacy, Mammogram Awareness and Screening Among Tertiary Hospital Women Patients. Journal of Cancer Education. 2016;28(5):1-6

17. Akfert KS, Çakıcı E, Çakıcı M. Üniversite öğrencilerinde sigara-alkol kullanımı ve aile sorunları ile ilişkisi. Anadolu Psikiyatri Dergisi 2009; 10: 40

18. Akvardar Y, Aslan B, Ekici ZB, Öğün E, Şimşek T. Dokuz Eylül Üniversitesi tıp fakültesi dönem II öğrencilerinde sigara, alkol, madde kullanımı. Bağımlılık Dergisi 2001; 2(2): 49-52.

19. Çapık C, Cingil D. Hemşirelik öğrencilerinde sigara kullanımı, bağımlılık düzeyi ve ilişkili etmenler. Kafkas J Med Sci 2013; 3(2):55-61.

20. İlhan F, Aksakal FN, İlhan MN, Aygün R. Gazi Üniversitesi Tıp Fakültesi ögrencilerinin sigara içme durumu. TSK Koruyucu Hekimlik Bülteni 2005; 4(4): 188-198.

21. Shoou-Yih Daniel Lee, Tzu-I Tsai. Accuracy in self-reported health literacy screening: a difference between men and women in Taiwan. BMJ Open 2013; 3-5 